\title{
Synthesis of Alginate Oligosaccharide (AOS) Using Different Solvents
}

\author{
Nathaniel Nainggolan $^{1}$, Seprianto ${ }^{1}$, Rinta Kusumawati ${ }^{2 *}$ \\ ${ }^{1}$ Program Studi Bioteknologi, Fakultas Ilmu-ilmu Kesehatan, Universitas Esa Unggul, Jalan Arjuna Utara No.9, , \\ Kebon Jeruk, Jakarta Barat, Indonesia \\ ${ }^{2}$ Balai Besar Riset Pengolahan Produk dan Bioteknologi Kelautan dan Perikanan, Jalan KS Tubun, Petamburan VI, \\ Slipi, Jakarta Pusat, Indonesia \\ *Corresponding Author: tanjung.1979@gmail.com
}

\section{ABSTRACT}

Alginate oligosaccharide (AOS) is an oligosaccharide synthesized by depolymerizing alginate and has various industrial applications. This research determines the best solvent and the optimal concentration of the best solvent to produce AOS. Peroxides and hydrochloric acid can be used as solvents, but the residue might cause some danger if the AOS extract is used for food or pharmaceutical purposes. Citric acid can be used as a solvent, but it is necessary to determine the optimum concentration to synthesize AOS. Citric acid concentration variations are $0.3 \mathrm{M}, 0.5 \mathrm{M}$, and $0.7 \mathrm{M}$. After that, the type of solvent varies, $3 \%$ (v/v) hydrogen peroxide, $0.3 \mathrm{M}$ hydrochloric acid, and $0.3 \mathrm{M}$ citric acid. AOS are measured by measuring the amount of reducing sugar using the DNS colorimetric method. The results were then submitted to a one-way ANOVA test followed by a post hoc Tukey Test $(\mathrm{P}<0,05)$. The result of the Tukey test shows that the $0.3 \mathrm{M}$ citric acid treatment significantly has the highest reducing sugar compared to the other solvents. The $0.3 \mathrm{M}$ citric acid solvent also has the highest AOS yield compared to the other solvents.

Keywords: alginate oligosaccharide, citric acid, hydrochloric acid, hydrogen peroxide, synthesis

\section{ABSTRAK}

Oligosakarida alginat (OSA) adalah polimer sederhana dari alginat yang dapat disintesis melalui proses kimiawi yaitu hidrolisis. Penggunaan bahan kimia dalam produksi bahan pangan, kosmetik, dan farmasetikal dimungkinkan selama dalam batas aman dan tidak meninggalkan residu yang melebihi batas aman. Senyawa ini cukup luas pemanfaatannya untuk kebutuhan industri. Penelitian bertujuan untuk mendapatkan jenis larutan yang dapat menghasilkan AOS melalui proses hidrolisis. Dalam penelitian digunakan asam sitrat $(0,3 ; 0,5$, dan $0,7 \mathrm{M})$, hidrogen peroksida (3\%), dan asam klorida (0,3 M). Hasil konsentrasi gula pereduksi diolah menggunakan uji ANOVA satu arah dan dilanjutkan dengan uji post hoc Tukey $(\mathrm{P}<0,05)$. Hasil uji post hoc Tukey menunjukkan bahwa perlakuan $\mathrm{B} 1$ dengan asam sitrat 0,3 $\mathrm{M}$ secara signifikan memiliki kadar gula pereduksi tertinggi dari seluruh pelarut.Larutan asam sitrat $0,3 \mathrm{M}$ juga menghasilkan rendemen tertinggi dari seluruh pelarut.

Kata Kunci : asam klorida, asam sitrat, hidrogen peroksida, oligosakarida alginat, sintesis 


\section{PENDAHULUAN}

Alginat merupakan polisakarida asam linear alami yang secara kimia tersusun oleh asam uronat $\alpha$-L-guluronat and $\beta$-Dmannuronat [1-3]. Alginat dapat diekstraksi dari semua spesies makroalga cokelat dari genus Macrocystis, Turbinaria, Padina dan Sargassum [4]. Alginat dan produk derivatifnya memiliki karakteristik biologis, kimiawi, dan fisik yang unik, seperti memiliki viskositas yang tinggi, mampu membentuk gel dengan ion kalsium, dapat berfungsi sebagai immunomodulator, dan dapat meregulasi pertumbuhan tumbuhan dan mikroflora usus [1,5-7]. Dengan demikian, peluang pemanfaatannya oleh banyak industri seperti industri pangan dan pakan, medis, kosmetik, tekstil, dan agrikultur sangat luas $[1,2,4]$. Oligosakarida alginat (OSA) adalah produk turunan alginat yang disintesis dengan proses depolimerisasi. OSA dapat disintesis secara enzimatis menggunakan enzim alginat liase atau secara kimiawi menggunakan metode hidrolisis asam atau degradasi oksidatif [1-3]. OSA lebih unggul karena memiliki kelarutan yang lebih baik dalam air dan bioaktivitas yang lebih tinggi dibandingkan dengan alginat [5]. Untuk itu, perlu ditetapkan metode sintesis yang mudah, biaya rendah, dan dapat diulang.

Dalam penelitian ini, sintesis OSA dilakukan secara kimiawi dengan pertimbangan kemudahan dalam mendapatkan bahan kimia dibandingkan jika menggunakan enzim. Enzim alginatliase cukup riskan untuk diproduksi sendiri dan tidak efisien dalam hal biaya produksi jika menggunakan enzim komersial. Metode sintesis OSA secara kimiawi yang digunakan dalam penelitian ini berdasarkan penelitian Yamasaki et al. dan Mao et al. [1,3]. Pada tahun 2011, Yamasaki et al. dan Mao et al. mengembangkan metode depolimerisasi alginat dengan menggunakan asam klorida dan oksidator hidrogen peroksida untuk menghidrolisis polimer alginat menjadi OSA [1,3]. Tetapi penggunaan asam klorida [8] dan hidrogen peroksida [9] dalam proses produksi bahan pangan dan farmasetikal dinilai membahayakan. Dalam penelitian, kedua bahan ini tetap digunakan sebagai pembanding. Alternatif lain adalah menggunakan asam lemah. Seperti yang dilaporkan oleh Horst et al. pada tahun 2011 bahwa asam lemah seperti asam fosfat dan asam asetat memiliki kemampuan untuk menghidrolisis limbah lignoselulosa menjadi D-glukosa dan memiliki efisiensi hidrolisis yang sebanding dengan asam kuat [10]. Sehingga dapat diinferensi bahwa alginat, yang merupakan polisakarida alami, dapat didepolimerisasi menjadi OSA dengan menggunakan asam lemah antara lain asam sitrat. Penggunaan asam sitrat untuk sintesis OSA belum dilaporkan dan senyawa ini aman untuk proses dalam produk pangan, non pangan, dan farmasi [11-14]. Tujuan dari penelitian ini adalah untuk mengoptimasi pelarut yang digunakan untuk hidrolisis alginat menjadi OSA.

\section{METODE}

\section{Bahan}

Penelitian ini menggunakan bahan sodium alginat yang diekstraksi dari rumput laut cokelat Sargassum crassifolium yang diperoleh dari Yogyakarta. Sintesis dan presipitasi oligosakarida alginat (OSA) dilakukan secara kimiawi dengan menggunakan bahan-bahan kimia yang dibeli dari Merck yang terdiri atas asam sitrat $\left(\mathrm{C}_{6} \mathrm{H}_{8} \mathrm{O}_{7}\right)$, asam klorida $(\mathrm{HCl})$, hidrogen peroksida $\left(\mathrm{H}_{2} \mathrm{O}_{2}\right)$, dan sodium hidroksida $(\mathrm{NaOH})$. Uji kadar gula pereduksi dengan metode DNS menggunakan bahan-bahan 3,5Dinitrosalisiklik (DNS), sodium hidroksida $(\mathrm{NaOH})$, fenol $\left(\mathrm{C}_{6} \mathrm{H}_{5} \mathrm{OH}\right)$, sodium bisulfat $\left(\mathrm{NaHSO}_{3}\right)$, dan Potasium natrium tartrat $\left(\mathrm{KNaC}_{4} \mathrm{H}_{4} \mathrm{O}_{6} \cdot 4 \mathrm{H}_{2} \mathrm{O}\right)$.

\section{Sintesis OSA Secara Kimiawi}

OSA kimiawi disintesis dengan menggunakan metode Yamasaki et al. modifikasi dengan menggunakan hidrolisis asam dan degradasi oksidatif Mao et. al. $[1,3]$. Sintesis OSA dari sodium alginat 
berlangsung karena adanya reaksi hidrolisis yang dapat memotong ikatan glikosidik sodium alginat dan mengurangi berat molekulernya $[1,3]$. OSA Dalam proses sintesis OSA kimiawi yang dikembangkan Yamasaki et al., sodium alginat diinkubasi dalam $200 \mathrm{ml}$ pelarut asam dengan konsentrasi sodium alginat sebanyak $1 \%$ dari jumlah larutan dalam suhu $121^{\circ} \mathrm{C}$ selama 80 menit. Metode ini juga menjadi acuan untuk penggunaan asam sitrat. Konsentrasi asam sitrat divariasi $0,3 \mathrm{M}, 0,5 \mathrm{M}$, dan $0,7 \mathrm{M}$.
Hidrogen peroksida dengan konsentrasi 3\% digunakan sebagai pelarut untuk degradasi oksidatif [3]. Berdasarkan penelitian pendahuluan, suhu inkubasi larutan sodium alginat perlu dimodifikasi menjadi $100^{\circ} \mathrm{C}$ dan untuk mengkompensasi berkurangnya suhu inkubasi sodium alginat maka waktu inkubasi diperpanjang menjadi 160 menit. Larutan alginat yang terhidrolisis didinginkan hingga suhu ruang dan dinetralisasi dengan $\mathrm{NaOH}$ dengan konsentrasi $1 \mathrm{M}$ hingga mencapai $\mathrm{pH}$ 7.0.

Tabel 1. Kode pelarut sodium alginat

\begin{tabular}{cl}
\hline Kode & \multicolumn{1}{c}{ Keterangan } \\
\hline A & Sodium alginat sebagai kontrol \\
B1 & Sodium alginat dihidrolisis dengan asam sitrat $\left(\mathrm{C}_{6} \mathrm{H}_{8} \mathrm{O}_{7}\right) 0,3 \mathrm{M}$ \\
B2 & Sodium alginat dihidrolisis dengan asam sitrat $\left(\mathrm{C}_{6} \mathrm{H}_{8} \mathrm{O}_{7}\right) 0,5 \mathrm{M}$ \\
$\mathrm{B} 3$ & Sodium alginat dihidrolisis dengan asam sitrat $\left(\mathrm{C}_{6} \mathrm{H}_{8} \mathrm{O}_{7}\right) 0,7 \mathrm{M}$ \\
C & Sodium alginat dihidrolisis dengan asam klorida $(\mathrm{HCl}) 0,3 \mathrm{M}$ \\
D & Sodium alginat dihidrolisis dengan hidrogen peroksida $\left(\mathrm{H}_{2} \mathrm{O}_{2}\right) 3 \%$ \\
\hline
\end{tabular}

Presipitasi dan Pengeringan Larutan OSA Kimiawi

OSA yang telah dinetralkan selanjutnya dipresipitasi dengan menggunakan etanol absolut mengacu pada proses penanganan ekstrak probiotik dari sumber gula lain dalam penelitian Widarnani et al. [15]. Presipitasi menggunakan perbandingan etanol dan OSA 2:1 (v/v). Etanol yang telah di presipitasi disentrifugasi dalam kecepatan $5000 \mathrm{rpm}$ selama 15 menit. OSA hasil sentrifugasi dikeringkan dengan konsentrator hingga kering. OSA bubuk diperoleh dengan penepungan OSA kering.

\section{Uji Kadar Gula Pereduksi OSA dengan Metode DNS}

Pengujian mengacu pada penelitian Garriga et al. [16]. Sebanyak $1 \mathrm{ml}$ larutan OSA 0,1\%, ditambahkan $1,5 \mathrm{ml}$ reagen DNS, hal yang sama dilakukan terhadap larutan alginat $0,1 \%$. Sampel uji dalam tabung tertutup kemudian diinkubasi pada $100^{\circ} \mathrm{C}$ selama 5 menit dan didinginkan hingga mencapai suhu ruang. Pengukuran absorbansi dilakukan pada panjang gelombang $550 \mathrm{~nm}$. Persamaan regresi linier dari kurva standar glukosa digunakan dalam menetapkan konsentrasi gula reduksi pada sampel.

\section{Analisis Statistik}

Kadar gula pereduksi sampel selanjutnya dianalisis gsecara statistik ANOVA satu arah dan dilanjutkan dengan uji Tukey $(\mathrm{p}<0,05)$ menggunakan perangkat lunak pengolah data SPSS (Versi 24 IBM $^{\circledR}$ SPSS $^{\circledR}$ Statistics, USA).

\section{HASIL DAN PEMBAHASAN}

\section{Rendemen OSA}

Hasil akhir dari proses secara kimiawi yang diperoleh dari setiap perlakuan adalah berupa padatan granuler kering kecoklatan. Berat OSA kering ditimbang dan dibandingkan dengan berat bahan baku yaitu sodium alginat untuk menghitung rendemen. Nilai rendemen tertinggi dapat digunakan untuk menandai jenis pelarut mana yang lebih berpeluang digunakan untuk sintesis OSA. Rendemen yang dihasilkan ditunjukkan dalam Tabel 2. 
Tabel 2. Rendemen OSA kering

\begin{tabular}{cccc}
\hline Kode & $\begin{array}{c}\text { Berat } \\
\text { Awal }(\mathbf{g})\end{array}$ & $\begin{array}{c}\text { Berat } \\
\text { Akhir }(\mathbf{g})\end{array}$ & $\begin{array}{c}\text { Rendemen } \\
(\mathbf{\%})\end{array}$ \\
\hline B1 & 2,00 & 1,06 & 53 \\
B2 & 2,00 & 1,02 & 51 \\
B3 & 2,00 & 1,96 & 98 \\
C & 2,00 & 0,34 & 17 \\
D & 30,00 & 0.46 & 23 \\
\hline
\end{tabular}

Perlakuan beda konsentrasi asam sitrat menunjukkan OSA kering dengan rendemen tertinggi pada perlakuan B3 dengan rendemen sebanyak $98 \%$. Hasil perhitungan rendemen dari perlakuan beda jenis larutan menunjukkan rendemen terendah pada perlakuan C. Dapat diketahui dari Tabel 2 tersebut bahwa ada perbedaan yang nyata bahwa perlakuan dengan asam sitrat menghasilkan rendemen yang jauh lebih tinggi dari perlakuan dengan peroksida dan asam klorida. Hidrolisis glikosida dalam suasana asam dilaporkan berhubungan erat dengan ikatan manuronat $(\mathrm{M})$ - guluronat $(\mathrm{G})$ dan stabilitas gugus karboksil yang tidak terdisosiasi. Pada suasana yang asam, ikatan G-M proses degradasi cepat terjadi dibandingkan pada ikatan M-G [17]. Hal tersebut dapat menjelaskan pada perlakuan dengan konsentrasi asam yang lebih tinggi memberikan hasil rendemen yang juga lebih tinggi, namun demikian perlu dipelajari lebih lanjut.

Tabel 3. Hasil uji ANOVA satu arah kadar gula pereduksi OSA

\begin{tabular}{clc}
\hline Kode & \multicolumn{1}{c}{ Jenis Perlakuan } & Kadar Gula Pereduksi (\%) \\
\hline A & Sodium Alginat (Kontrol) & $0,007 \pm 0,003$ \\
B1 & Hidrolisis asam sitrat $(0,3 \mathrm{M})$ & $0,088 \pm 0,0042$ \\
B2 & Hidrolisis asam sitrat $(0,5 \mathrm{M})$ & $0,046 \pm 0,0057$ \\
B3 & Hidrolisis asam sitrat $(0,7 \mathrm{M})$ & $0,039 \pm 0,0028$ \\
C & Hidrolisis asam klorida $(0,3 \mathrm{M})$ & $0,063 \pm 0,0071$ \\
D & Degradasi Oksidatif dengan Peroksida $(0,3 \mathrm{M})$ & $0,06 \pm 0,0099$ \\
\hline
\end{tabular}

Uji ANOVA Satu Arah $(p=0.000)$

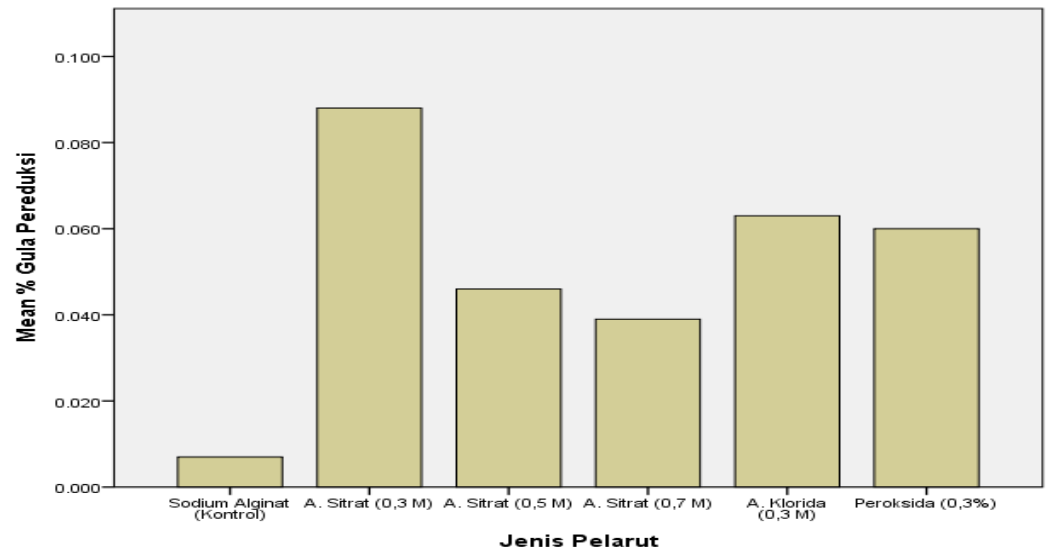

Gambar 1. Kadar Gula Pereduksi Hasil Perlakuan

\section{Kadar Gula Pereduksi}

Kadar gula pereduksi yang paling tinggi dapat ditemukan pada pelarut asam sitrat $0,3 \mathrm{M}$. Hasil tersebut menunjukkan masih banyak alginat yang tidak terhidrolisis karena diperkirakan proses perlakuan yang diberikan tidak mengurai gugus karbonil ikatan polimer dalam molekul glikosidik yang dimiliki alginat. Hidrolisis ikatan glikosidik sodium alginat secara kimiawi menyebabkan aldehida dapat direduksi oleh reagen DNS, jika reaksi ini tinggi maka kadar gula pereduksi dikuantifikasi oleh 
spektrofotometer sebagai tingginya jumlah OSA yang tersintesis[16].

Dengan menggunakan ANOVA satu arah $(\mathrm{F}(5,6)=41,467, p=0,000)$ diketahui adanya perbedaan yang signifikan antara konsentrasi gula pereduksi sodium alginat dan OSA yang disintesis secara kimiawi.Sodium alginat yang dihidrolisis dengan pelarut asam sitrat $0,3 \mathrm{M}$ menghasilkan kadar gula pereduksi yang tertinggi dari seluruh perlakuan secara signifikan berdasarkan uji post hoc Tukey $(0,088 \% \pm$ $0,0042, p=0,000$ ). Hal ini menandakan bahwa pelarut tersebut berpotensi dapat mensintesis OSA dalam jumlah yang lebih tinggi dibandingkan dengan perlakuan lain. Konsentrasi gula reduksi terendah terdapat pada perlakuan B2 $(0,046 \% \pm 0,0057, p=0,003)$ dan B3 $(0,039 \% \pm 0,0028, p=0,001)$. Berkurangnya kadar gula pereduksi dengan meningkatnya konsentrasi larutan asam sitrat dapat menjelaskan meningkatnya rendemen seiring meningkatnya konsentrasi pelarut asam sitrat. Hasil uji post hoc Tukey yang menunjukkan adanya perbedaan signifikan antara perlakuan B1, B2, dan B3yang menunjukkan bahwa peningkatan konsentrasi asam sitrat dapat mengurangi jumlah OSA yang tersintesis.

Selain adanya perbedaan kadar gula pereduksi yang signifikan antara konsentrasi pelarut asam sitrat, ditemukan pula adanya perbedaan kadar gula pereduksi signifikan antar setiap jenis pelarut. Hasil uji post hoc Tukey menunjukkan perbedaan signifikan antara kadar gula pereduksi OSA yang disintesis dengan larutan asam sitrat $0,3 \mathrm{M}$ dengan OSA yang disintesis dengan asam klorida $0,3 \mathrm{M}(0,063 \% \pm$ $0,0071, p=0,04)$ dan hidrogen peroksida $3 \%$ $(0,06 \% \pm 0,0099, p=.0,024)$. Hasil uji Tukey tersebut menunjukkan bahwa walaupun larutan asam sitrat belum dilaporkan digunakan untuk sintesis OSA,namun asam sitrat dapat digunakan untuk menghidrolisis polisakarida [10]. Kemampuan asam sitrat untuk menghidrolisis OSA lebih efektif dari asam klorida dan hidrogen peroksida, hal ini menunjukkan asam sitrat berpotensi untuk digunakan untuk sintesis OSA dan didukung dengan sifatnya yang ramah lingkungan dibandingkan dengan menggunakan asam klorida atau asam kuat lain [18]. Penelitian lebih lanjut perlu dilakukan terutama untuk melakukan optimasi suhu dan waktu pemanasan.
Degradasi oksidatif juga dapat dioptimasi lebih lanjut untuk menghasilkan konsentrasi OSA yang lebih tinggi dengan menggunakan katalis $\mathrm{Fe}^{2+}$ dan pemberian pra-perlakuan asam pada sodium alginat karena dilaporkan memiliki kemampuan sinergisitk dan meningkatkan efisiensi dalam proses degradasi oksidatif menggunakan hidrogen peroksida [18].

\section{KESIMPULAN}

Perlakuan sintesis OSA dengan menggunakan asam sitrat $0,3 \mathrm{M}$ merupakan perlakuan terbaik dengan kadar gula pereduksi tertinggi $0,088 \%$ dan rendemen OSA 53\%.

\section{UCAPAN TERIMA KASIH}

Para Penulis berterima kasih kepada Balai Besar Riset Pengolahan Produk dan Bioteknologi Kelautan dan Perikanan yang telah memberikan kesempatan, mendanai, dan menyediakan laboratorium untuk penelitian ini hingga penelitian selesai.

\section{DAFTAR PUSTAKA}

[1] Yamasaki Y, Yokose T, Nishikawa T, Kim D, Jiang Z, Yamaguchi $K$, et al. Effects of alginate oligosaccharide mixtures on the growth and fatty acid composition of the green alga Chlamydomonas reinhardtii. Journal of Bioscience and Bioengineering. 2012;113:112-6. https://doi.org/10.1016/j.jbiosc.2011.09.00 9.

[2] Zilda DS, Yulianti Y, Sholihah RF, Subaryono S, Fawzya YN, Irianto HE. A novel bacillus sp. Isolated from rotten seaweed: Identification and characterization alginate lyase its produced. Biodiversitas. 2019;20:116672.

https://doi.org/10.13057/biodiv/d200432.

[3] Mao S, Zhang T, Sun W, Ren X. The depolymerization of sodium alginate by oxidative degradation. Pharmaceutical Development and Technology. 2012;17:763-9. 
https://doi.org/10.3109/10837450.2011.58 3927.

[4] Pakidi CS, Suswati E. Potensi dan Pemanfaatan Bahan Aktif Alga Cokelat Sargassum sp. Octopus 2016;5:488-98.

[5] Subaryono, Perangiangin R, Suhartono MT, Zakaria FR. Imunomodulator Activity of Alginate Oligosaccharides from Alginate Sargassum crassifolium. Jurnal Pengolahan Hasil Perikanan Indonesia. 2017;20:63-73.

[6] González A, Castro J, Vera J, Moenne A. Seaweed Oligosaccharides Stimulate Plant Growth by Enhancing Carbon and Nitrogen Assimilation, Basal Metabolism, and Cell Division. Journal of Plant Growth Regulation. 2013;32:443-8. https://doi.org/10.1007/s00344-012-93091.

[7] Li M, Li G, Shang Q, Chen X, Liu W, Pi $\mathrm{X}$, et al. In vitro fermentation of alginate and its derivatives by human gut microbiota. Anaerobe. 2016;39:19-25. https://doi.org/10.1016/j.anaerobe.2016.02 .003 .

[8] Agency for Toxic Substances and Disease Registry. Medical Management Guidelines for Hydrogen Chloride. https://www.atsdr.cdc.gov/MHMI/mmg17 3.pdf; 2014.

[9] Agency for Toxic Substances and Disease Registry. Hydrogen peroxide (H 2 O 2 ). Managing Hazardous Materials Incidents. https://www.atsdr.cdc.gov/MHMI/mmg17 4.pdf; 2014.

[10] Horst D, Behainne J, Petter R. Analysis of Hydrolysis Yields By Using Different Acids for Bioethanol Production From Brazilian Woods. XVII International Conference on Industrial Engineering and Operations Management. 2011:14.

[11] Tampubolon K, Sihombing FN, Purba Z, Samosir STS, Karim S. Potensi metabolit sekunder gulma sebagai pestisida nabati di Indonesia. Kultivasi. 2018;17:683-93. https://doi.org/10.24198/kultivasi.v17i3.18 049.

[12] Surest AH, Ovelando R, Nabilla MA. Fermentasi Buah Markisa Menjadi Asam Sitrat.Jurnal Teknik Kimia. 2013;19:1521.
[13] Tang P, Ji B, Sun G. Whiteness improvement of citric acid crosslinked cotton fabrics: $\mathrm{H} 2 \mathrm{O} 2$ bleaching under alkaline condition. Carbohydrate Polymers. 2016;147:139-45. https://doi.org/10.1016/j.carbpol.2016.04. 007.

[14] Yasmin Q, Meindrawan B, Pamela VY. Karakterisasi Edible film dari Karagenan , Lilin Lebah dan Asam Sitrat. Jurnal Teknologi Pengolahan Pertanian. 2020;2:27-35.

[15] Widanarni; Noermala JIS. Prebiotik, probiotik, dan sinbiotik untuk mengendalikan koinfeksi Vibrio harveyi dan IMNV pada udang vaname. Jurnal Akuakultur Indonesia. 2014;13:11-20.

[16] Garriga M, Almaraz M, Marchiaro A. Determination of Reducing Sugars in Extracts of Undaria pinnatifida (harvey) algae by UV-visible spectrophotometry (DNS method).Actas de Ingeniería. 2017:173-9.

[17] Holtan S, Zhang Q, Strand WI, SkjåkBræk G. Characterization of the Hydrolysis Mechanism of Polyalternating Alginate in Weak Acid and Assignment of the Resulting MG-Oligosaccharides by NMR Spectroscopy and ESI-Mass Spectrometry. Biomacromolecules. 2006;7:2108-21.

[18] Liu J, Yang S, Li X, Yan Q, Reaney MJT, Zhenqiang J. Alginate Oligosaccharides: Production, Biological Activities, and Potential Applications. Comprehensive Reviews in Food Science and Food Safety. 2019;18. https://doi.org/10.1111/15414337.12494. 